\title{
Exendin-4 protects endothelial cells from lipoapoptosis by PKA, PI3K, eNOS, p38 MAPK, and JNK pathways
}

\author{
Özlem Erdogdu*, Linnéa Eriksson*, Hua Xu', Åke Sjöholm, Qimin Zhang \\ and Thomas Nyström
}

Department of Clinical Science and Education, Karolinska Institutet, Södersjukhuset AB, SE-118 83 Stockholm, Sweden

'Department of Pathophysiology, Ningxia Medical University, Yinchuan, Ningxia 750004, People's Republic of China *(Ö Erdogdu and L Eriksson contributed equally to this work.)
Correspondence should be addressed to T Nyström Email thomas.nystrom@ sodersjukhuset.se

\begin{abstract}
Experimental studies have indicated that endothelial cells play an important role in maintaining vascular homeostasis. We previously reported that human coronary artery endothelial cells (HCAECs) express the glucagon-like peptide 1 (GLP1) receptor and that the stable GLP1 mimetic exendin- 4 is able to activate the receptor, leading to increased cell proliferation. Here, we have studied the effect of exendin-4 and native GLP1 (7-36) on lipoapoptosis and its underlying mechanisms in HCAECs. Apoptosis was assessed by DNA fragmentation and caspase-3 activation, after incubating cells with palmitate. Nitric oxide (NO) and reactive oxidative species (ROS) were analyzed. GLP1 receptor activation, PKA-, PI3K/Akt-, eNOS-, p38 MAPK-, and JNK-dependent pathways, and genetic silencing of transfection of eNOS were also studied. Palmitate-induced apoptosis stimulated cells to release NO and ROS, concomitant with upregulation of eNOS, which required activation of p38 MAPK and JNK. Exendin-4 restored the imbalance between NO and ROS production in which ROS production decreased and NO production was further augmented. Incubation with exendin-4 and GLP1 (7-36) protected HCAECs against lipoapoptosis, an effect that was blocked by PKA, PI3K/Akt, eNOS, p38 MAPK, and JNK inhibitors. Genetic silencing of eNOS also abolished the anti-apoptotic effect afforded by exendin-4. Our results support the notion that GLP1 receptor agonists restore eNOS-induced ROS production due to lipotoxicity and that such agonists protect against lipoapoptosis through PKA-PI3K/Akt-eNOS-p38 MAPK-JNK-dependent pathways via a GLP1 receptor-dependent mechanism.
\end{abstract}

\section{Key Words}

- Endothelial nitric oxide synthase

- Exendin-4

- GLP1

- Human coronary endothelial cells

- Lipoapoptosis

\section{Introduction}

Type 2 diabetes and insulin resistance are associated with atherosclerosis, which is the major cause of morbidity and mortality in these patients. Experimental studies have indicated that the vascular endothelium plays an important role in maintaining the balance between vasoconstriction and vasodilatation, coagulation and fibrinolysis, proliferation, and apoptosis (Furchgott \& Vanhoutte 1989). Damage of vascular cells by proatherosclerotic risk factors, such as lipids and inflammatory cytokines, might be an early marker for the development of atherosclerosis and vascular complications (Verma et al. 2003). Several studies have reported that free fatty acids (FFAs) impair the 
integrity of the endothelial monolayer and its barrier function, leading to enhanced endothelial apoptosis (Chai \& Liu 2007, Artwohl et al. 2008), a key factor contributing to endothelial dysfunction (Dimmeler et al. 2002). Nitric oxide (NO) is the single most important factor for maintaining endothelial function, and mice with a deletion of the gene for endothelial NO synthase (eNOS) show accelerated atherosclerosis (Kuhlencordt et al. 2001). Circulating FFAs interfere with eNOS (Steinberg et al. 2000) and endothelial function in humans (Tripathy et al. 2003).

Glucagon-like peptide-1 (GLP1) is a brain gut insulinotropic hormone that plays an important role in the regulation of glucose homeostasis and thus has been applied in clinical treatment of diabetes (Drucker \& Nauck 2006). Exendin-4, a stable incretin mimetic and GLP1 receptor agonist, has been shown to promote glucosedependent insulin secretion in vitro (Parkes et al. 2001). Besides its insulinotropic action, exendin-4 may also exert direct beneficial effects on endothelial function. Exendin-4 reduces macrophage adhesion to the endothelium, an early step in the formation of atherosclerotic plaques and endothelial dysfunction (Arakawa et al. 2010). Acute administration of exendin- 4 in humans prevents endothelial dysfunction induced by ischemia reperfusion injury (Ha et al. 2011) and after a high-fat meal load (Koska et al. 2010), effects suggested to be GLP1 receptor and NO dependent (Nyström et al. 2004).

We previously reported that human coronary artery endothelial cells (HCAECs) express the GLP1 receptor and that exendin- 4 is able to activate the receptor, leading to increased cell proliferation, involving the eNOS pathway (Erdogdu et al. 2010). GLP1 has also been described as an anti-apoptotic factor in different cells, including cardiomyocytes (Ravassa et al. 2011), neuronal cells (Li et al. 2009), and vein endothelial cells (Schisano et al. 2012, Shiraki et al. 2012). The aim of our study was to investigate the putative protective effect of exendin-4 and GLP1 against lipoapoptosis of HCAECs and attempt to address the pathways involved in imparting such an effect.

\section{Materials and methods}

\section{Cell culture and incubation}

Normal primary HCAECs isolated from normal human coronary arteries (passage 5-13) obtained from Clonetics (Lonza, Walkersville, MD, USA) were grown in EGM-2 MV medium supplemented with hydrocortisone, human epidermal growth factor, 5\% FBS, vascular endothelial growth factor, human fibroblast growth factor-B, R3-IGF1, ascorbic acid, and gentamicin/amphotericin $\mathrm{B}$ at $37^{\circ} \mathrm{C}$ in a humidified atmosphere $\left(5 \% \mathrm{CO}_{2}, 95 \%\right.$ air $)$ as recommended by the supplier. Confluent cultures were detached by trypsin-2-[2-(Bis(carboxymethyl)amino) ethyl-(carboxymethyl)amino]acetic acid and seeded onto tissue culture dishes for evaluation of apoptosis and western blotting.

To examine the effect of exendin- 4 on apoptosis, eNOS, and Akt phosphorylation, HCAECs were grown to $90 \%$ confluence, followed by incubation overnight in serum-deficient EGM medium containing 0.5\% FBS and $2 \mathrm{mM}$ L-glutamine. L-NG-nitroarginine methyl ester hydrochloride (L-NAME) (1 mM), LY294002 (1 $\mu \mathrm{M})$, Rp-cAMP[S] $(10 \mu \mathrm{M})$, p-38 MAPK inhibitor SB203580 $(10 \mu \mathrm{M})$, JNK inhibitor SP600125 $(5 \mu \mathrm{M})$, Akt inhibitor IV $(0.5 \mu \mathrm{M})$, (6R)-5,6,7,8-tetrahydrobiopterin dihydrochloride (BH4) $(10 \mu \mathrm{M})$, and ( \pm )-6-hydroxy-2,5,7,8-tetramethylchromane-2-carboxylic acid (Trolox) $(1 \mathrm{mM})$ or vehicle were added $1 \mathrm{~h}$ before palmitate $(125 \mu \mathrm{M}$, a concentration that has recently been demonstrated to induce apoptosis (Artwohl et al. 2008)), and exendin-4 stimulation and continuously present during the 24-h incubation. All materials, unless stated, were purchased from Sigma-Aldrich.

\section{NO measurement}

Direct measurements of NO release from HCAECs were performed using the cell-impermeable fluorescence indicator DAF-2 as described (Nakatsubo et al. 1998). Cells were incubated in 12-well plates in the presence or absence of palmitate with/without exendin- 4 or vehicle in the serum-deficient medium for $24 \mathrm{~h}$. The cells were subsequently washed twice in $\mathrm{KRB}$ containing in $(\mathrm{mM})$ $135 \mathrm{NaCl}, 3.6 \mathrm{KCl}, 5 \mathrm{NaHCO}_{3}, 0.5 \mathrm{NaH}_{2} \mathrm{PO}_{4}, 0.5 \mathrm{MgCl}_{2}$, $1.5 \mathrm{CaCl}_{2}$, and 10 HEPES, $\mathrm{pH} 7.4$, followed by an incubation with $5 \mu \mathrm{M}$ DAF- 2 in $0.5 \mathrm{ml} \mathrm{KRB}$ for $2 \mathrm{~h}$, at $37^{\circ} \mathrm{C}$, using the eNOS substrate L-arginine $(100 \mu \mathrm{M})$ as positive control. At the end of the incubation, supernatants were transferred into black microplates and the fluorescence was measured with a fluorescence microplate reader Infinite M200 (Tecan Group Ltd., Männedorf, Germany) at excitation wavelength of $488 \mathrm{~nm}$ and emission $515 \mathrm{~nm}$. Results were normalized to the protein concentrations determined using BCA kits after the cells in each well were lysed in a lysis buffer containing in $(\mathrm{mM})$ $80 \mathrm{Na}_{2} \mathrm{HPO}_{4}, 20 \mathrm{NaH}_{2} \mathrm{PO}_{4}, 100 \mathrm{NaCl}$, and 1\% Triton $\mathrm{X}-100, \mathrm{pH} 7.5$.

Published by Bioscientifica Ltd. 


\section{Western blot analysis}

Western blotting was applied to quantify the total and phosphorylated eNOS (Ser $\left.{ }^{1177}\right)$, Akt $1 / 2 / 3\left(\operatorname{Ser}^{473}\right)$, p38 MAPK (Thr ${ }^{180} /$ Tyr $\left.^{182}\right)$, or JNK $\left(\mathrm{Thr}^{183} / \mathrm{Tyr}^{185}\right)$ proteins and performed as described previously (Zhang \& Hintze 2006).

\section{Measurement of intracellular reactive oxygen species}

Intracellular reactive oxygen species (ROS) levels were measured using Image-iT LIVE Green Reactive Oxygen Species Detection Kit (Molecular Probes, Life Technologies Europe BV) as described previously (Suh et al. 2010). Briefly, the assay is based on 5-(and-6)-carboxy-2', $7^{\prime}$-dichlorodihydrofluorescein diacetate (carboxyH2DCFDA), a fluorogenic marker that will be cleaved upon the presence of ROS. HCAECs were seeded into sixwell plates. When reaching 80\% confluence, cells were first kept overnight in serum-deficient EGM medium containing $0.5 \% \mathrm{FBS}$ and $2 \mathrm{mM}$ L-glutamine followed by a 24-h incubation in the presence or absence of palmitate or vehicle, with or without exendin-4. Cells were then washed with Hank's balanced salt solution (HBSS) before adding $50 \mu \mathrm{M}$ carboxy-H2DCFDA to each well. After $30 \mathrm{~min}$ of incubation at $37^{\circ} \mathrm{C}$, excess probe was removed by washing the cells again with HBSS. HCAECs were then lysed in PBS containing 1\% Triton X-100. Carboxy-DCF fluorescence in cell lysates was detected at an excitation/ emission wavelength of 495/529 nm using a microplate reader (Tecan Group Ltd.). The fluorescence intensity was normalized against the protein concentration of each individual well.

\section{Determination of caspase-3 activity}

Caspase-3 activity, as a measure of apoptosis, was determined using a fluorometric substrate, Z-DEVD-AMC (EnzChek Caspase-3 assay kit Molecular probes, Life Technologies Europe BV) as described previously (Lincz 1998). Twenty-four hours after stimulation with palmitate or vehicle w/wo exendin-4, cells were incubated in $50 \mu \mathrm{l}$ Z-DEVD-AMC substrate at room temperature for $30 \mathrm{~min}$. Substrate cleavage was quantified fluorometrically at $342 \mathrm{~nm}$ excitation and $441 \mathrm{~nm}$ emission with a fluorescent plate reader (Tecan Group Ltd.).

\section{DNA fragmentation}

DNA fragmentation, another marker of apoptosis, in HCAECs was assayed by the cell death detection kit
ELISA plus (Roche Diagnostics Scandinavia AB), according to the manufacturer's instructions. The ELISA measures cytoplasmic DNA-histone complexes that increase after apoptosis-associated DNA fragmentation.
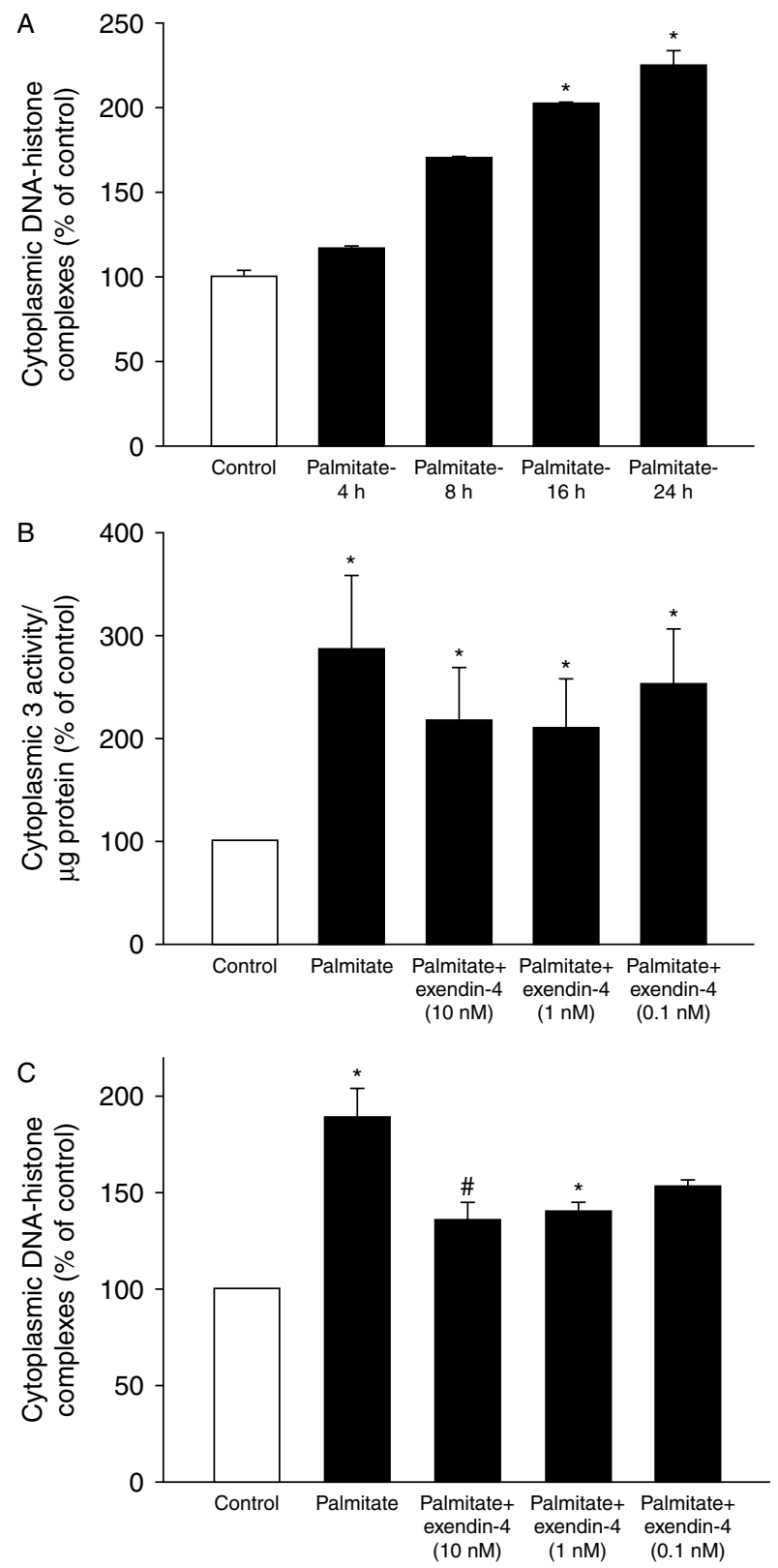

Figure 1

Exendin-4 blocks increased apoptosis induced by palmitate in HCAECs. Lipoapoptosis depends on the exposure time (A). Caspase-3 activation (B) and DNA fragmentation (C) measured in HCAECs exposed to palmitate $(125 \mu \mathrm{M})$ for $24 \mathrm{~h}$, alone or in combination with different concentrations of exendin-4 (0.1-10 nM). Results are normalized by protein concentration in the incubation wells and expressed as mean percentage of control \pm s.E.M. ${ }^{*} P<0.05$ for a chance difference vs controls by ANOVA, ${ }^{\#} P<0.05$ vs palmitate. Results derived from seven (A and $B$ ) or six $(C)$ independent experiments are shown.

Published by Bioscientifica Ltd. 


\section{Gene silencing}

The cells were seeded into a $100 \mathrm{~mm}$ dish at a density of $2.5 \times 10^{5}$ cells per well and incubated for $24 \mathrm{~h}$ at $37^{\circ} \mathrm{C}$ in complete medium. The cells were washed twice with culture medium without serum and supplement. Control siRNA/eNOS siRNA $(10 \mathrm{nM})$ was mixed and incubated with SilenceMag according to the standard protocol (Oz Biosciences, Marseille, France). After incubation with a magnetic field for $15 \mathrm{~min}$, the magnet was removed from the culture plate. Eight to twenty-four hours post-transfection, the media in the cell culture plate were replaced with complete medium containing 5\% FBS and then further incubated for $24 \mathrm{~h}$. The cells were harvested and centrifuged at $200 \boldsymbol{g}$ for $2 \mathrm{~min}$ to remove the supernatant.

\section{Isolation of total RNA and real-time PCR}

Total RNA was extracted from HCAECs treated with eNOS siRNA and control siRNA, using Aurum Total RNA Mini kit Bio-Rad, according to the manufacturer's instructions. cDNA was prepared using Script cDNA Synthesis kit, Bio-Rad (Life Science Research). The PCR mixture contained, in a final volume of $20 \mu \mathrm{l}, 4 \mu \mathrm{l}$ cDNA, $10 \mu \mathrm{l} \mathrm{KAPA}$ SYBR FAST qPCR mastermix (Kapa Biosystems, Woburn, MA, USA), and corresponding primers. The gene expression level was normalized to the housekeeping gene, $\beta$-actin.

\section{Statistical analyses}

Each assay was repeated a minimum of three times. All data are presented as mean \pm s.E.M. Statistical analyses of differences between groups were performed by one-way and two-way ANOVA followed by the post hoc tests Student-Newman-Keuls and Dunn-Bonferroni.

\section{Results}

\section{Exendin-4 decreases HCAEC lipoapoptosis (caspase-3 activation and DNA fragmentation)}

As shown in Fig. 1A, lipoapoptosis depends on its exposure time, cells incubated with $125 \mu \mathrm{M}$ palmitate for $24 \mathrm{~h}$ in serum-deficient EGM medium (containing $0.5 \%$ FBS and $2 \mathrm{mM}$ L-glutamine) exhibited the most significant increase in DNA fragmentation compared with other time points, as well as the control cells. All subsequent experiments were therefore conducted using $125 \mu \mathrm{M}$ palmitate over $24 \mathrm{~h}$. By contrast, palmitate-exposed cells co-incubated with exendin- 4 at various concentrations (0.1-10 nM) displayed a tendency to decrease caspase-3 activation compared with cells incubated with palmitate alone; however, the difference was not statistically significant (Fig. 1B). All experiments were conducted using $125 \mu \mathrm{M}$ palmitate over $24 \mathrm{~h}$. Figure 1C shows that DNA fragmentation was also increased in HCAECs incubated with $125 \mu \mathrm{M}$ palmitate compared with control cells. This increase was blunted when cells were co-incubated with $10 \mathrm{nM}$ exendin-4 (Fig. 1C).

\section{Exendin-4 and GLP1 protect HCAECs from palmitate-induced apoptosis via a GLP1 receptor-dependent pathway}

Many effects of GLP1 on the heart and the endothelium appear to be due to the formation of the DPP-4 metabolite GLP1 (9-36) (Ban et al. 2008, Nathanson et al. 2009). In order to examine whether the effects of exendin- 4 were conveyed through a GLP1 receptor-dependent pathway, we introduced GLP1, its major metabolite GLP1 (9-36), and the GLP1 receptor antagonist exendin (9-39). Incubating the cells with palmitate and exendin- 4 in the

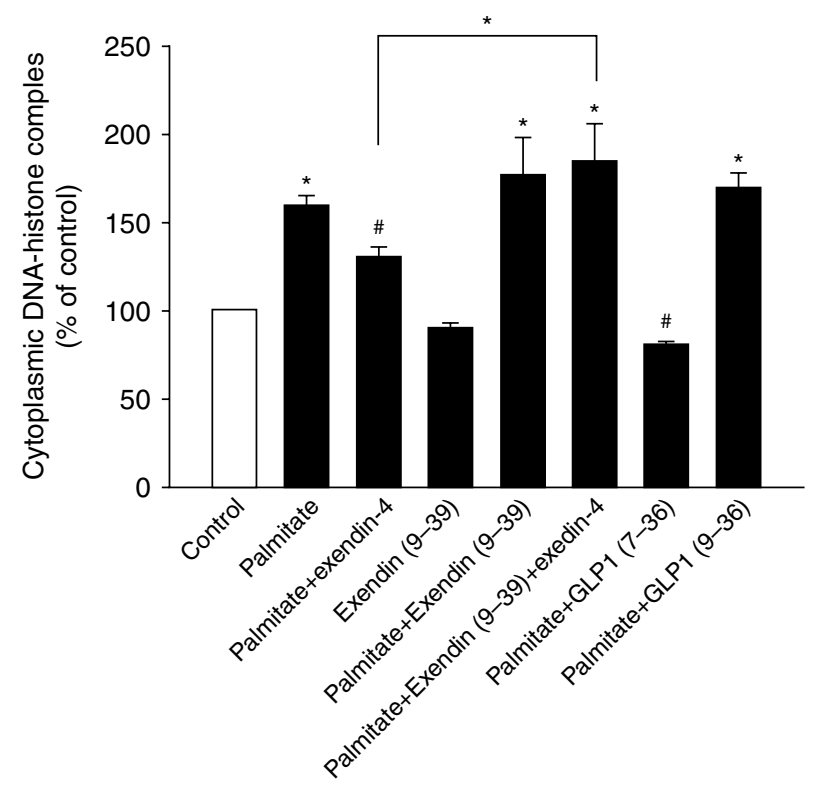

Figure 2

The protective effect of exendin-4 and GLP1 against lipoapoptosis is mediated through the GLP1 receptor. DNA fragmentation measured in HCAECs stimulated w/wo palmitate $(125 \mu \mathrm{M})$ for $24 \mathrm{~h}$ in the presence or absence of the indicated peptides (exendin-4, $10 \mathrm{nM}$; exendin (9-39)), $10 \mathrm{nM}$; GLP1 (7-36), $100 \mathrm{nM}$, added every $12 \mathrm{~h}$; GLP1 (9-36), $100 \mathrm{nM})$. Results are expressed as mean percentage of control \pm s.E.M. ${ }^{*} P<0.05$ vs control; ${ }^{\#} P<0.05$ vs palmitate. Results derived from 4 to 11 independent experiments are shown. 
presence of GLP1 receptor antagonist exendin (9-39) led to loss of exendin-4 protection against lipoapoptosis (Fig. 2). Incubation of the cells with GLP1 also protected against palmitate-induced apoptosis but with a greater potency than that conferred by exendin-4. Interestingly, the GLP1 (9-36) metabolite was not able to protect the HCAECs against apoptosis (Fig. 2).

\section{The anti-apoptotic action of exendin-4 is mediated by activation of PKA- and PI3K/Akt-dependent signaling pathways}

Most of the activities initiated by binding of exendin- 4 to its receptor on the surface of cells are mediated by an elevation in intracellular cAMP levels and PKA activity. We therefore examined whether blocking PKA activation countered the anti-apoptotic effect imposed by exendin-4. Cells were incubated with $125 \mu \mathrm{M}$ palmitate for $24 \mathrm{~h}$ in the presence or absence of $10 \mu \mathrm{M}$ Rp-cAMP[S], a specific inhibitor of PKA, and the extent of apoptosis was analyzed (Fig. 3A). Incubating the cells with Rp-cAMP[S] alone did not affect cellular apoptosis. However, when cells were incubated with palmitate and exendin- 4 in the presence of Rp-cAMP[S], the anti-apoptotic action of exendin- 4 was completely lost (Fig. 3A), indicating that the protective effect of exendin-4 against lipoapoptosis requires cAMP/PKA activation. In order to address whether cAMP could mimic the effect of exendin-4, we introduced a PKA agonist, Sp-cAMP[S]. Consistent with the above results, Sp-cAMP[S] blocked the increase in apoptosis induced by palmitate with an efficacy similar to that of exendin-4 (Fig. 3B). As we recently showed that exendin-4 activates eNOS through Akt phosphorylation in HCAECs (Erdogdu et al. 2010), we investigated whether palmitate exerts any effect on basal and exendin-4 stimulated Akt activation, a downstream kinase of the PI3K pathway, which was monitored by phosphorylation at $\mathrm{Ser}^{473}$. We observed that, while palmitate alone had no effects on Akt phosphorylation at Ser ${ }^{473}$, exendin-4 enhanced Akt phosphorylation at $\operatorname{Ser}^{473}$ (Fig. 4A). By contrast, incubating the cells with palmitate caused a slight, but statistically significant, increase in Akt protein expression. In addition, exposure to both palmitate and exendin-4 further augmented expression of Akt (data not shown). We next examined the role of PI3K and Akt in the prevention of apoptosis. Cells were incubated with $125 \mu \mathrm{M}$ palmitate in the presence or absence of LY294002 and Akt IV (which are selectively blocking PI3K and Akt respectively) and the extent of apoptosis was analyzed. LY294002 and Akt IV alone did not affect cellular apoptosis. However, both LY294002 (Fig. 4B) and Akt IV (Fig. 4C) countered the protection against the DNA fragmentation induced by palmitate, indicating that this anti-apoptotic effect of exendin-4 involves PI3K/Akt signaling pathways.

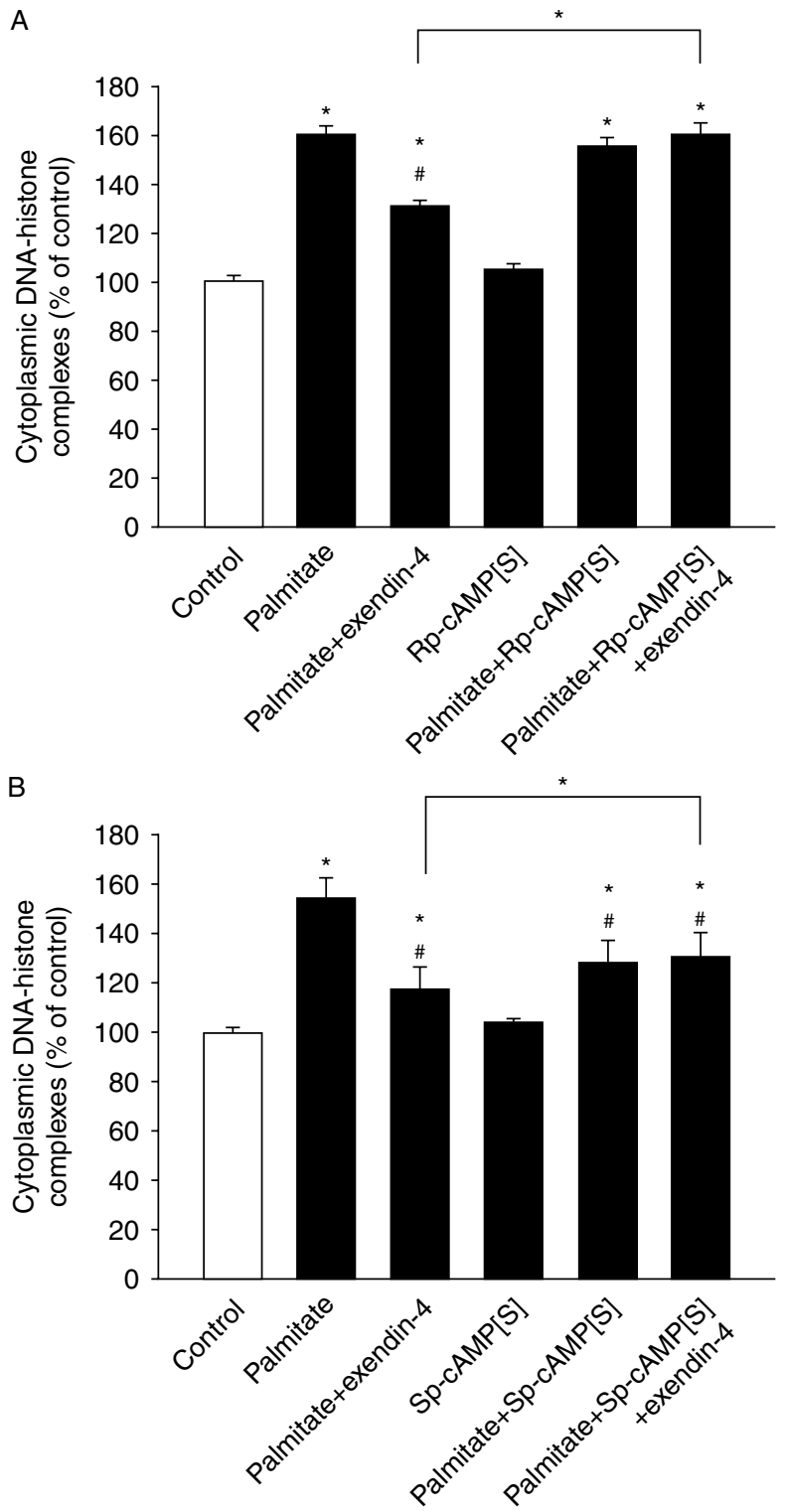

Figure 3

PKA involvement in the protective effect of exendin-4 against lipoapoptosis. Cells were incubated for $24 \mathrm{~h}$ with palmitate $(125 \mu \mathrm{M})$ and/or the PKA antagonist Rp-CAMP[S] (A, $10 \mu \mathrm{M})$ or the PKA agonist Sp-CAMP[S] $(B, 10 \mu \mathrm{M})$ in the presence or absence of exendin-4 $(10 \mathrm{nM})$. Results are expressed as mean percentage of control \pm s.E.M. ${ }^{*} P<0.05$ vs control; ${ }^{\#} P<0.05$ vs palmitate. Results derived from five to six independent experiments (each in duplicate) are shown. 


\section{Palmitate enhances basal eNOS phosphorylation}

To determine whether palmitate and exendin-4 (alone and in combination) influences eNOS activity, we examined activation, in a time course manner up to

A
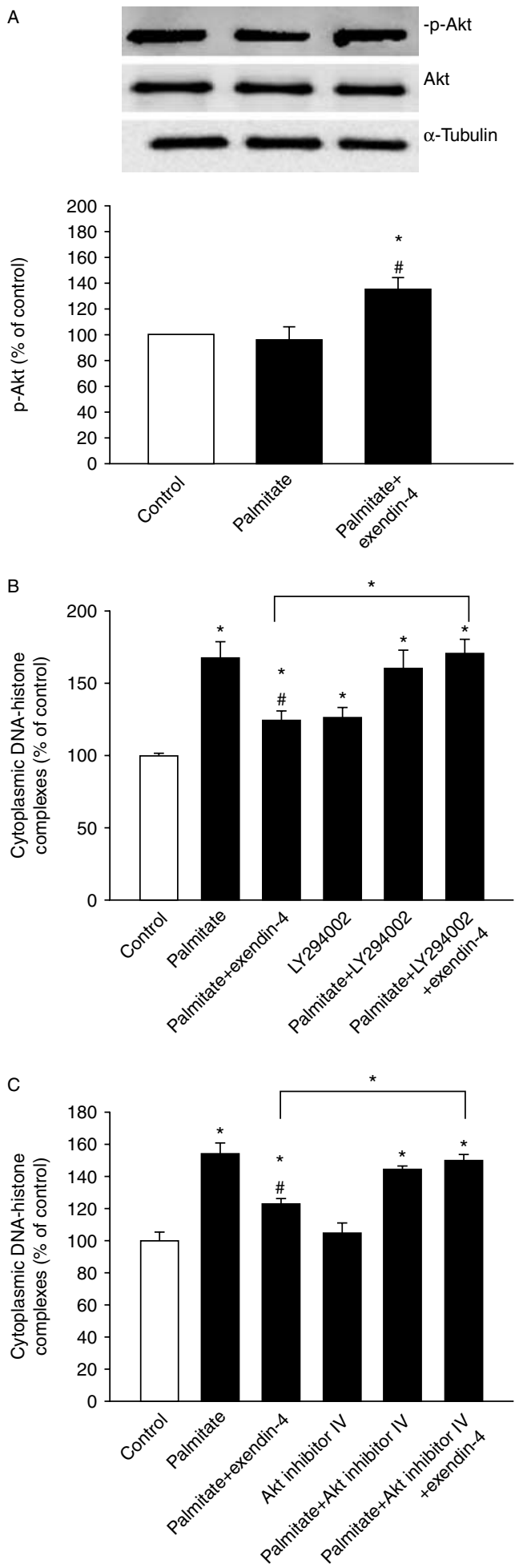

http://jme.endocrinology-journals.org DOI: 10.1530/JME-12-0166

C) 2013 Society for Endocrinology Printed in Great Britain
$24 \mathrm{~h}$, of the enzyme by measuring its phosphorylation at Ser ${ }^{1177}$. As shown in Fig. 5A, enhanced phosphorylation of eNOS was observed already after $10 \mathrm{~min}$ and further on with palmitate. By contrast, exendin-4 enhanced eNOS activation after 30 min with a decreased activation after $24 \mathrm{~h}$ (Fig. 5A). Entirely consistent with the above findings, NO production by the HCAECs was significantly enhanced by palmitate (Fig. 5B). Furthermore, co-incubation of the cells with palmitate and exendin- 4 further augmented NO production, approaching the effect produced by the eNOS substrate L-arginine (Fig. 5B).

\section{Exendin-4 decreases palmitate-induced ROS production}

As it is known that oxidative stress can elicit apoptosis, we decided to examine the influence of palmitate and exendin-4 on intracellular ROS production in the HCAECs. The cellular ability to produce ROS was measured by DCF fluorescence. This reaction is mainly started by hydrogen peroxide (Royall \& Ischiropoulos 1993). Similarly, as in the case of apoptosis, palmitate was found to increase DCF fluorescence compared with control cells. However, this enhancement was decreased when cells were incubated with exendin-4 (Fig. 5C). We next incubated cells with the essential reduced cofactor $\mathrm{BH} 4$, a key factor in eNOS catalysis, i.e. the ratio between reduced and oxidized $\mathrm{BH} 4$ tightly control ROS formation. Restoration of $\mathrm{BH} 4$ also, to some extent, reduced ROS production (Fig. 5D) to the same level as observed by exendin-4 (Fig. 5C).

\section{Protective effect of exendin-4 against lipoapoptosis is mediated by eNOS activation}

We next investigated whether blocking eNOS activation affected the anti-apoptotic effect of exendin-4. Cells were incubated with palmitate for $24 \mathrm{~h}$ in the presence or absence of the eNOS inhibitor L-NAME ( $1 \mathrm{mM})$ and rates of

\section{Figure 4}

Involvement of PI3K and Akt in the anti-apoptotic effect of exendin-4. Cells were incubated with palmitate $(125 \mu \mathrm{M})$ for $24 \mathrm{~h}$ in the presence or absence of exendin-4 (10 nM) as indicated and phosphorylation of Akt (p-Akt) measured. The bar plot (A) shows the summarized data of the band intensities after being normalized to total Akt protein and $\alpha$-tubulin. DNA fragmentation was measured in HCAECs w/wo palmitate $(0.125 \mathrm{mM})$ for $24 \mathrm{~h}$, alone or in combination with exendin-4 (10 nM), in the absence or presence of the PI3K inhibitor LY294002 (B, $1 \mu \mathrm{M})$ or the Akt IV inhibitor $(C, 0.5 \mu \mathrm{M})$. Results are expressed as mean percentage of control \pm S.E.M. ${ }^{*} P<0.05$ vs control; ${ }^{\#} P<0.05$ vs palmitate. Representative data from three to eight independent experiments are shown.

Published by Bioscientifica Ltd. 
A
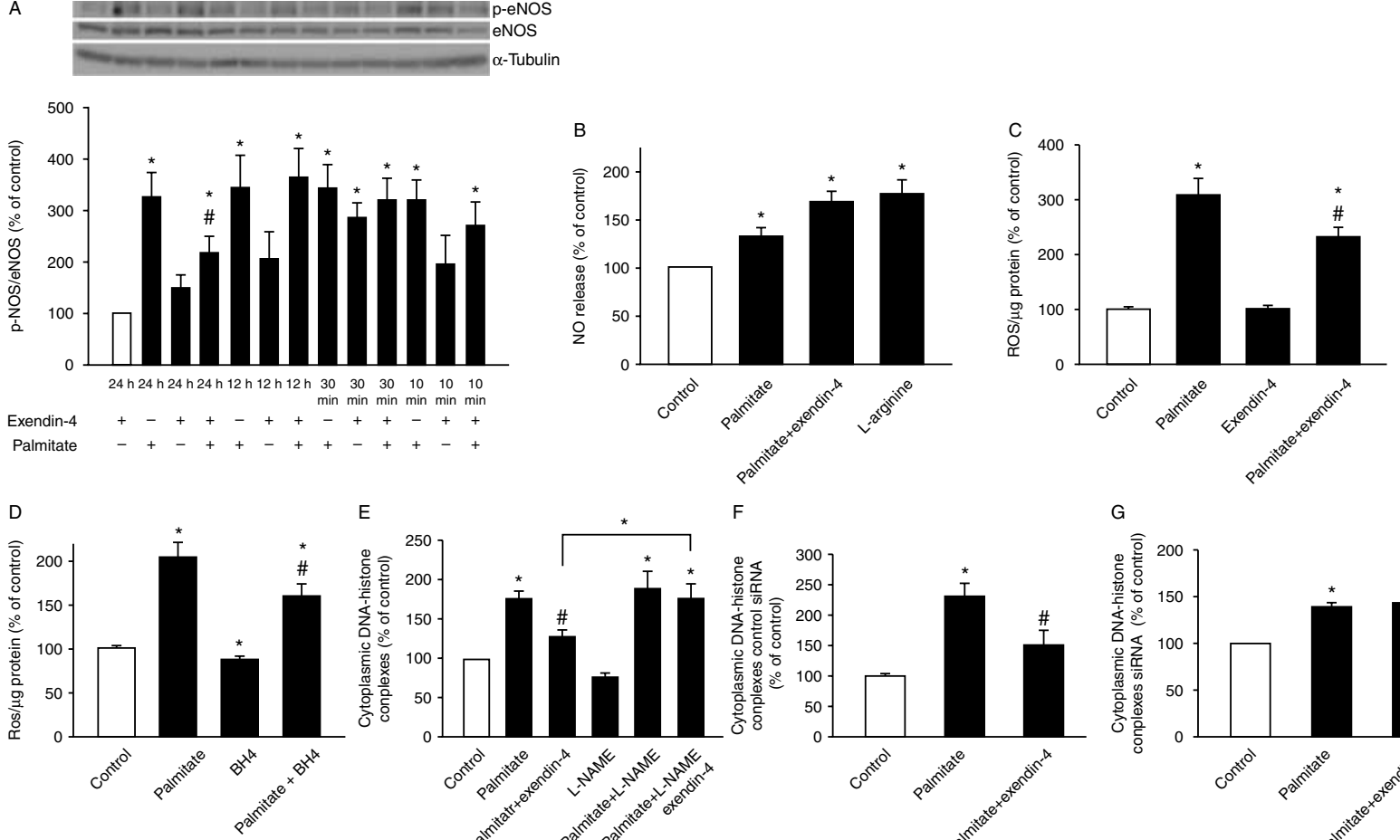

E $\mathrm{F}$
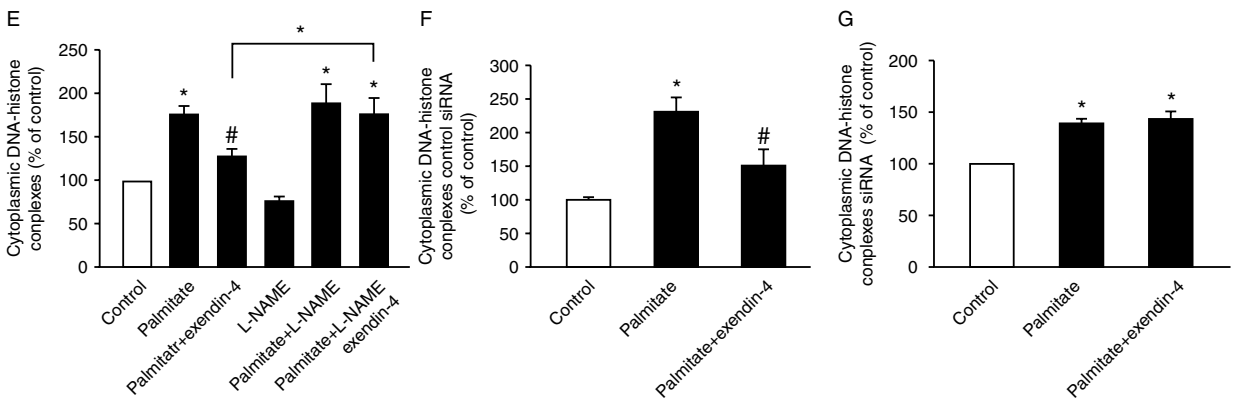

\section{Figure 5}

Involvement of NO in lipoapoptosis and protection by exendin-4. Cells were first incubated, in a time course manner, with palmitate $(125 \mu \mathrm{M})$ in the presence or absence of exendin-4 (10 nM) as indicated (A). The bar plot (A) shows the summarized data of the band intensities of p-eNOS after being normalized to eNOS protein. 24-h incubation with exendin-4 significantly decreased eNOS activity (A), concomitant with an increase in NO production in cells treated with palmitate as shown in (B). The NO released into the buffer was measured and normalized to the protein content in each well. The effect of exendin-4 on palmitate-induced ROS production was also decreased as shown in (C), an effect that was mimicked after incubation with the eNOS cofactor BH4 (D), suggesting that some of the effect might be due to an uncoupled eNOS. (E, F and $G$ ) The protective effect of exendin-4 against lipoapoptosis is eNOS dependent. DNA fragmentation was measured in HCAECs stimulated w/wo palmitate $(125 \mu \mathrm{M})$ for $24 \mathrm{~h}$, alone or in combination with exendin-4 (10 nM), in the presence or absence of specific eNOS inhibitor L-NAME $1 \mathrm{Mm}(\mathrm{E})$, control SiRNA (F), or eNOS siRNA transfection (G). Data are expressed as mean percentage of control \pm S.E.M. ${ }^{*} P<0.05$ vs control; ${ }^{\#} P<0.05$ vs palmitate. Representative data from 3 to 12 independent experiments are shown.

abolished by the eNOS siRNA. These findings altogether indicate that the protective effect of exendin- 4 against lipoapoptosis in HCAECs is mediated by eNOS activation.

\section{Exendin-4 inhibits palmitate-induced activation of p38 MAPK and JNK}

p38 MAPK and JNK are involved in stress responses by regulating many cellular functions. As p38 MAPK and JNK have been demonstrated to be involved in the development of insulin resistance and cardiovascular diseases (Seeger et al. 2005), we examined the effect of palmitate on all three major MAPKs (p38 MAPK, JNK, and ERK1/2) because all are involved in the regulation of cell survival and apoptosis. p38 MAPK and JNK can be activated by phosphorylation at $\mathrm{Thr}^{180} / \mathrm{Tyr}^{182}$ and $\mathrm{Thr}^{183} / \mathrm{Tyr}^{185}$ http://jme.endocrinology-journals.org DOI: 10.1530/JME-12-0166
C 2013 Society for Endocrinology Printed in Great Britain 
respectively, thereby regulating its catalytic activity. As shown in Fig. 6A and B, palmitate caused a significant increase in both p38 MAPK and JNK phosphorylation compared with control cells. This increment was significantly reduced by co-incubation with palmitate and exendin-4. However, incubating the cells with palmitate with/without exendin-4 did not significantly alter the phosphorylation of ERK1/2 (data not shown).
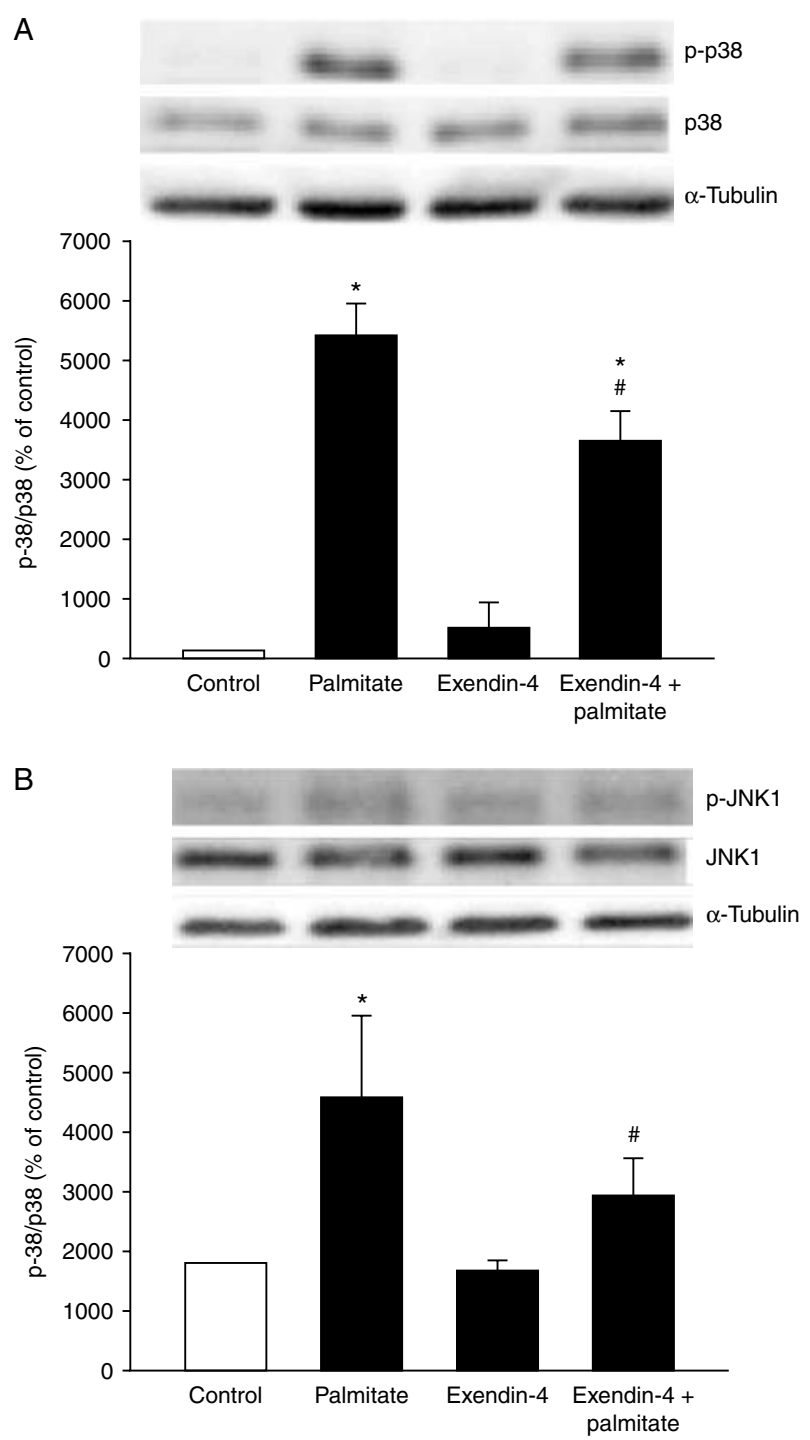

Figure 6

Exendin-4 inhibits palmitate-induced activation of p38 MAPK and JNK. Cells were incubated with palmitate $(125 \mu \mathrm{M})$ for $24 \mathrm{~h}$ in the presence or absence of exendin- $4(10 \mathrm{nM})$ as indicated. The bar plot shows the summarized data of the band intensities after being normalized against the total levels of p38 MAPK or JNK protein respectively and is expressed as mean percentage of control \pm S.E.M. Results derived from four (A) or five (B) independent experiments are shown. ${ }^{*} P<0.05$ vs control; ${ }^{*} P<0.05$ vs palmitate.

http://jme.endocrinology-journals.org DOI: 10.1530/JME-12-0166
๑) 2013 Society for Endocrinology Printed in Great Britain
The anti-apoptotic effect of exendin- 4 is mediated by p38 MAPK- and JNK-dependent mechanisms

We next examined whether blocking p38 MAPK activation affected the protective effect of exendin-4 against lipoapoptosis. HCAECs were incubated with $125 \mu \mathrm{M}$ palmitate for $24 \mathrm{~h}$ in the presence or absence of $10 \mu \mathrm{MSB} 203580$, a specific inhibitor for $\mathrm{p} 38 \mathrm{MAPK}$, and the extent of apoptosis was analyzed (Fig. 7A). As mentioned previously, palmitate induced a robust increase in apoptosis, which was attenuated by exendin-4. However, SB203580 alone significantly reduced cellular apoptosis. SB203580 at $10 \mu \mathrm{M}$ abolished some of the palmitateinduced apoptosis. By contrast, when cells were incubated with palmitate and exendin- 4 in the presence of SB203580, the anti-apoptotic effect of exendin- 4 was blocked by co-incubation with SB203580. As JNK has also been shown to mediate cellular apoptosis, we examined whether blocking JNK activation by SP600125, a specific inhibitor for JNK, also abolished the protective effect of exendin- 4 on palmitate-induced apoptosis. Our results indicate that, in the presence of SP600125, exendin-4 failed to prevent the increase in apoptosis induced by palmitate (Fig. 7B). We next incubated cells with both SB203580 $(10 \mu \mathrm{M})$ and SP600125 $(5 \mu \mathrm{M})$, which nearly completely abolished the induced apoptosis (Fig. 7C). Finally, we used an antioxidant (Trolox) that completely inhibited ROS production (Fig. 7D), with no such effect on apoptosis (Fig. 7E). However, our results indicate that, in the presence of SB203580 and SP600125, exendin-4 failed to prevent the increase in apoptosis induced by palmitate (Fig. 7C). Taken together, these data suggest that the anti-apoptotic effect of exendin-4 is dependent on p38 MAPK and JNK activities, however not necessarily due to oxidative stress.

\section{Discussion}

The main findings of this study are as follows: long-term exposure of HCAECs to palmitate induces apoptosis, eNOS activity, ROS release, and production of NO. Exendin- 4 and GLP1, but not the degradation metabolite GLP1 (9-36), confer protection against this lipoapoptosis. The antiapoptotic effect of exendin- 4 is mediated through the GLP1 receptor and involves PKA-, PI3K-, eNOS-, p38 MAPK-, and JNK-dependent pathways.

Elevated levels of circulating FFAs frequently seen in patients with type 2 diabetes (Chai \& Liu 2007) are suggested to decrease NO bioactivity, either by increased destruction or an impaired eNOS activity. As endothelial dysfunction is tightly coupled to a decrease in NO

Published by Bioscientifica Ltd 
A

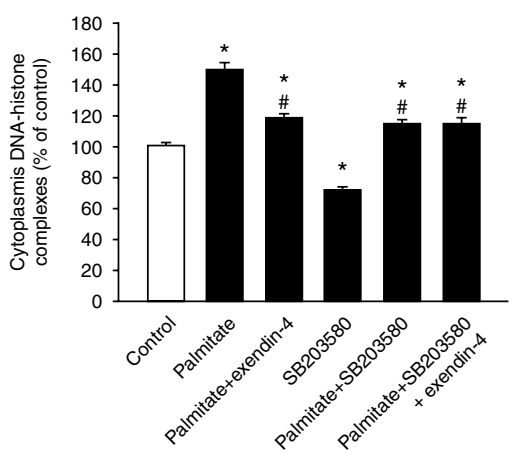

D

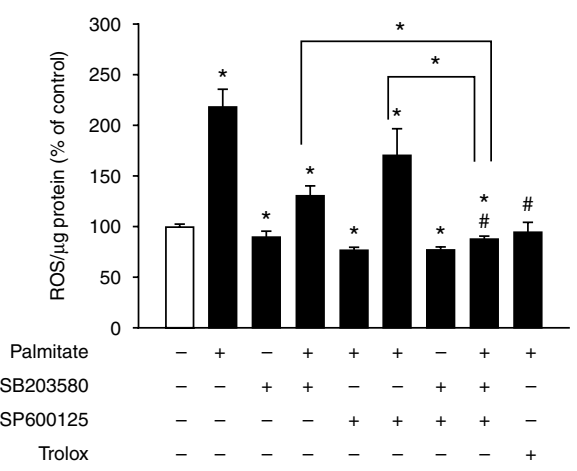

B

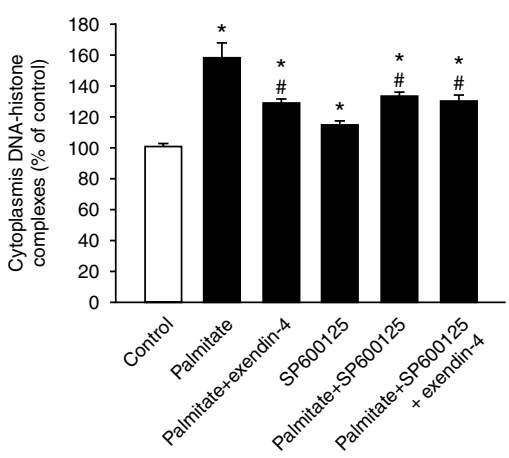

C
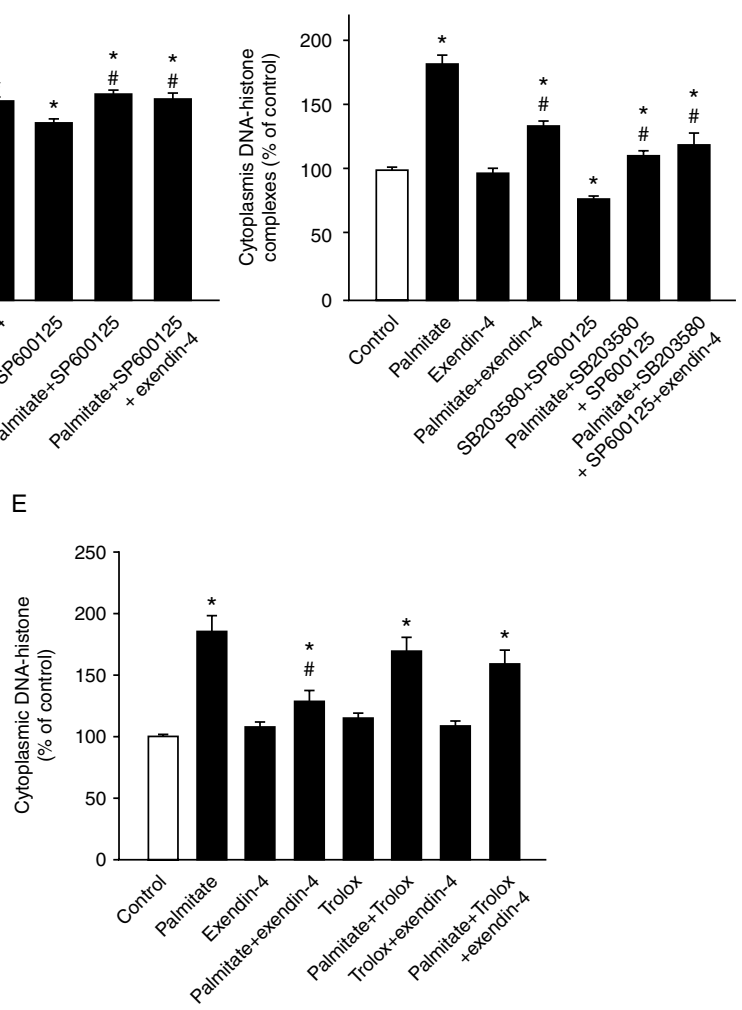

Figure 7

Involvement of p38 MAPK and JNK in the anti-apoptotic effect of exendin-4. DNA fragmentation measured in HCAECs stimulated w/wo palmitate $(125 \mu \mathrm{M})$ for $24 \mathrm{~h}$, alone or in combination with exendin-4 $(10 \mathrm{nM})$, in the absence or presence of the p38 MAPK inhibitor SB203580 (10 $\mu \mathrm{M})(\mathrm{A})$ or the JNK inhibitor SP600125 (5 $\mu \mathrm{M})$ (B), or in combination (C). The antioxidant

bioavailability (Harrison 1997), we would have expected palmitate to downregulate eNOS activity (Kim et al. 2005, Wang et al. 2006). Paradoxically, eNOS phosphorylation was robustly increased in HCAECs exposed to palmitate. Accordingly, NO production was also increased by palmitate and so was the release of ROS. Notably, a number of studies have demonstrated that NO release is increased under diabetic conditions ( $\mathrm{Xu} \& \mathrm{Zou} 2009$ ). It was recently shown that palmitate stimulates ROS production in aortic endothelial cells through PKCdependent activation (Inoguchi et al. 2000). Usually, ROS are scavenged through multiple defense mechanisms, and excessive levels of ROS can impede these systems and promote breakdown NO, thereby exacerbating the oxidative stress (Tesfamariam \& Cohen 1992, Cosentino et al. 1997). In hyperlipidemic conditions, any of the three NOS enzymes might yield superoxide anion (usually referred to uncoupling of eNOS), known to react rapidly with NO,
Trolox (1 mM) completely abolished ROS production (D), without any effect on apoptosis (E). Results derived from four to six independent experiments (in duplicates) are shown and expressed as mean percentage of controls \pm S.E.M. ${ }^{*} P<0.05$ vs control; ${ }^{\#} P<0.05$ vs palmitate.

leading to production of the highly pro-oxidant peroxynitrite (Zou et al. 2004). Peroxynitrite is known to be toxic and triggers many different cellular responses including apoptosis of the cells (Laursen et al. 2001, Zou et al. 2004). It was recently demonstrated that treatment of human aortic endothelial cells with high concentrations of glucose increases the eNOS expression (due to uncoupling of the enzyme) and subsequently causes oxidative stress (Cosentino et al. 1997). Moreover, short-term exposure to a triglyceride-rich fat emulsion, mimicking the elevated FFAs in our current in vitro work, impairs endothelium-dependent vasorelaxation, with a concomitant increase in eNOS activity in rat conduit artery rings ex vivo (Nathanson et al. 2009). Our results confirm the above and previous suggestions, i.e. palmitate induces an imbalance between NO and ROS release, and that the enhancement of eNOS activity might be due to uncoupling of this enzyme. One causative factor for eNOS 
uncoupling is a deficient amount of the essential cofactor of eNOS, i.e. BH4 (Verhaar et al. 2004). Supporting that notion, eNOS activity was substantially decreased by exendin- 4 treatment in our study, with a concomitant reduction in ROS levels and mimicked by $\mathrm{BH} 4$ restoration. By contrast, prolonged exposure of the HCAECs to exendin-4 further augmented NO production, a crucial factor in regulation and coordination of endothelial function and apoptosis (Calles-Escandon \& Cipolla 2001).

GLP1 and its derivates have previously been assigned an anti-apoptotic role in murine HL-1 cardiomyocytes (Ravassa et al. 2011), pancreatic $\beta$-cells (Cunha et al. 2009, Kim et al. 2010), and neuronal cells (Li et al. 2009). Very recently, it was also shown that exendin-4 protects pancreatic $\beta$-cells against lipoapoptosis by interfering with the JNK signaling pathway. Recent studies have revealed differential effects of exendin-4 and GLP1 on vascular functions (Ban et al. 2008, Nathanson et al. 2009), suggesting the existence of a signaling pathway independent of the classical GLP1 receptor. To this end, we attempted to address whether the anti-apoptotic effect of exendin- 4 was mediated by the GLP1 receptor using the GLP1 receptor antagonist exendin (9-39). The antiapoptotic effect induced by exendin-4 was indeed abolished by the GLP1 receptor antagonist, thus suggesting GLP1 receptor-dependent action of the peptide. Interestingly, the major metabolite GLP1 (9-36), which possesses no affinity to the classical GLP1 receptor (Knudsen \& Pridal 1996, Ban et al. 2008), failed to reduce palmitate-induced apoptosis in HCAECs, adding further credence in favor of the view that the protective effect of exendin-4 is mediated through the known GLP1 receptor in these cells. It was previously reported that most effects of GLP1 are mediated through activation of cAMP/PKA signaling (Brubaker \& Drucker 2004). Using a PKA inhibitor and activator, we show that PKA activation is both sufficient and required for exendin- 4 to confer its protective actions. Thus, stimulation of the PKA pathway by exendin- 4 may convey the protective effect of the peptide against lipoapoptosis in HCAECs.

Further downstream the PI3K/Akt pathway is known to be involved in protection from apoptosis in different cell types (Piro et al. 2008). Akt plays a crucial role in insulin signaling and its suppression can lead to both insulin resistance and apoptosis (Piro et al. 2008). By contrast, palmitate did not influence Akt phosphorylation in the current work. The addition of exendin-4 significantly enhanced phosphorylation of Akt and decreased the amount of apoptotic cells. Furthermore, the antiapoptotic effect of exendin-4 was prevented when endothelial cells were cultured with LY294002 and Akt inhibitor IV respectively, suggesting that exendin-4 requires activation of the PI3K/Akt pathway to protect HCAECs from lipoapoptosis. Consistent with our findings, previous findings in other cell types also indicate that the anti-apoptotic actions of GLP1 are mediated through a PI3K-dependent signaling pathway (Kimura et al. 2009).

eNOS plays a pivotal role in endothelial cell proliferation and survival (Calles-Escandon \& Cipolla 2001). This enzyme is activated by exendin- 4 through phosphorylation, leading to enhanced NO production and this effect is dependent on the activation of the PI3K/Akt pathway (Erdogdu et al. 2010). In addition, eNOS can also be activated by PKA or Akt, resulting in increased NO production (Schulz et al. 2005). Previous work has indicated that the activity of eNOS is diminished in endothelial apoptosis induced by multiple proapoptotic factors (Dimmeler \& Zeiher 1999). By contrast, we demonstrated in this study that paradoxically increased eNOS activity is associated with enhancement of lipoapoptosis and that co-incubation with exendin- 4 attenuated this proapoptotic effect of palmitate. The anti-apoptotic effect of exendin- 4 was abolished when HCAECs were cultured with L-NAME. In addition, genetic silencing of transfection of eNOS abrogated the protective effect of exendin-4 against lipoapoptosis, demonstrating that the anti-apoptotic action of exendin- 4 is also mediated by an eNOS-dependent pathway in the HCAECs.

Recently, it was reported that high levels of ROS not only damage cells by oxidizing DNA and protein but also indirectly damage cells by activating a variety of stresssensitive intracellular signaling pathways, such as p38 MAPK and JNK (Klaunig et al. 2010). In the current study, palmitate increased the phosphorylation of both p38 MAPK and JNK and apoptosis in HCAECs. Furthermore, co-incubation of the cells with exendin-4 significantly decreased the phosphorylation levels of these kinases, with a concomitant reduction in endothelial cell apoptosis. That inhibition of p38 MAPK and JNK with specific inhibitors completely abolished the proapoptotic effects of palmitate, suggesting that palmitate induces apoptosis in HCAECs through p38 MAPK- and JNK-dependent pathways. This finding is consistent with a recent report demonstrating that palmitate also triggers cytokine secretion via both $\mathrm{p} 38$ MAPK and JNK pathways in differentiated THP-1 cells, a model of human macrophages (Haversen et al. 2009). Recently, it was also shown that exendin- 4 protects $\beta$-TC6 insulinoma cell line against lipoapoptosis by interfering with the JNK signaling pathway (Xiang et al. 2012). It has also been reported that p38 MAPK activation alone

Published by Bioscientifica Ltd. 
accounts for palmitate-induced apoptosis in HCAECs (Chai $\&$ Liu 2007). Interestingly, the anti-apoptotic effect of exendin- 4 was also abolished by specific inhibitors of p38 MAPK and JNK, indicating that activation of these kinases not only contributes to increased lipoapoptosis but also that their suppression plays an important role in HCAEC survival caused by exendin- 4 . In the current study, the antioxidant Trolox inhibited palmitate-induced ROS production, similar to the inhibitors of p38 MAPK and JNK kinases. Surprisingly, Trolox did not evoke any antiapoptotic actions. Reason for that is not clear; however, we cannot exclude that other ROS are behind the involvement of p38 MAPK and JNK kinases upon apoptosis. Recently, it was demonstrated that exendin-4 inhibits cytotoxic induced $\beta$-cell death via a decreased phosphorylation of both p38 MAPK and JNK, through PKA signaling pathways (Kawasaki et al. 2010), which is in line with our observation.

In conclusion, we demonstrate that palmitate activates eNOS to stimulate NO release and that p38 MAPK and JNK signaling pathways are involved in palmitate-induced ROS production and lipoapoptosis. Exendin-4 and GLP1 protect HCAECs against lipoapoptosis, which is mediated through the GLP1 receptor involving PKA-, eNOS-, p38 MAPK-, and JNK-dependent pathways. These effects, demonstrated in vitro, might serve to limit the adverse consequences of the macrovascular complications of type 2 diabetes as dysfunction of endothelial cells is believed to contribute to premature development of atherosclerosis.

\section{Declaration of interest}

$\mathrm{T} \mathrm{N}$ has received consultancy fees from Eli Lilly. A $\mathrm{S}$ has received research grants, consultancy fees, lecture honoraria, and fees for expert testimony from Eli Lilly.

\section{Funding}

Financial support was provided through the regional agreement on medical training and clinical research (ALF) between Stockholm County Council and the Karolinska Institute and by the Swedish Society for Medical Research, the Swedish Society of Medicine, Stiftelsen Serafimerlasarettet, the Swedish Heart and Lung foundation, Eli Lilly Amylin Alliance, the European Foundation for the Study of Diabetes, Karolinska Institutet Foundations, and Stiftelsen Olle Engkvist Byggmästare.

\section{Author contribution statement}

All authors contributed to the study conception and design. Ö $E, L E, H X$ and $Q Z$ conducted the study. All authors analyzed the data. Ö E, $\AA$ S, and $\mathrm{T} N$ wrote the first draft of the paper. L E conducted the additional experiments due to the revision. All authors commented and took part of the revision of the paper.

http://jme.endocrinology-journals.org DOI: 10.1530/JME-12-0166
(C) 2013 Society for Endocrinology Printed in Great Britain

\section{References}

Arakawa M, Mita T, Azuma K, Ebato C, Goto H, Nomiyama T, Fujitani Y, Hirose T, Kawamori R \& Watada H 2010 Inhibition of monocyte adhesion to endothelial cells and attenuation of atherosclerotic lesion by a glucagon-like peptide-1 receptor agonist, exendin-4. Diabetes 59 1030-1037. (doi:10.2337/db09-1694)

Artwohl M, Lindenmair A, Sexl V, Maier C, Rainer G, Freudenthaler A, Huttary N, Wolzt M, Nowotny P, Luger A et al. 2008 Different mechanisms of saturated versus polyunsaturated FFA-induced apoptosis in human endothelial cells. Journal of Lipid Research 49 2627-2640. (doi:10.1194/jlr.M800393-JLR200)

Ban K, Noyan-Ashraf MH, Hoefer J, Bolz SS, Drucker DJ \& Husain M 2008 Cardioprotective and vasodilatory actions of glucagon-like peptide 1 receptor are mediated through both glucagon-like peptide 1 receptordependent and -independent pathways. Circulation 117 2340-2350. (doi:10.1161/CIRCULATIONAHA.107.739938)

Brubaker PL \& Drucker DJ 2004 Minireview: glucagon-like peptides regulate cell proliferation and apoptosis in the pancreas, gut, and central nervous system. Endocrinology 145 2653-2659. (doi:10.1210/en. 2004-0015)

Calles-Escandon J \& Cipolla M 2001 Diabetes and endothelial dysfunction: a clinical perspective. Endocrine Reviews 22 36-52. (doi:10.1210/er.22.1.36)

Chai W \& Liu Z 2007 p38 mitogen-activated protein kinase mediates palmitate-induced apoptosis but not inhibitor of nuclear factor-kappaB degradation in human coronary artery endothelial cells. Endocrinology 148 1622-1628. (doi:10.1210/en.2006-1068)

Cosentino F, Hishikawa K, Katusic ZS \& Luscher TF 1997 High glucose increases nitric oxide synthase expression and superoxide anion generation in human aortic endothelial cells. Circulation 96 25-28. (doi:10.1161/01.CIR.96.1.25)

Cunha DA, Ladriere L, Ortis F, Igoillo-Esteve M, Gurzov EN, Lupi R, Marchetti P, Eizirik DL \& Cnop M 2009 Glucagon-like peptide-1 agonists protect pancreatic $\beta$-cells from lipotoxic endoplasmic reticulum stress through upregulation of BiP and JunB. Diabetes $\mathbf{5 8}$ 2851-2862. (doi:10.2337/db09-0685)

Dimmeler S \& Zeiher AM 1999 Nitric oxide-an endothelial cell survival factor. Cell Death and Differentiation 6 964-968. (doi:10.1038/sj.cdd. 4400581)

Dimmeler S, Haendeler J \& Zeiher AM 2002 Regulation of endothelial cell apoptosis in atherothrombosis. Current Opinion in Lipidology 13 531-536. (doi:10.1097/00041433-200210000-00009)

Drucker DJ \& Nauck MA 2006 The incretin system: glucagon-like peptide-1 receptor agonists and dipeptidyl peptidase- 4 inhibitors in type 2 diabetes. Lancet 368 1696-1705. (doi:10.1016/S0140-6736(06)69705-5)

Erdogdu O, Nathanson D, Sjöholm A, Nyström T \& Zhang Q 2010 Exendin-4 stimulates proliferation of human coronary artery endothelial cells through eNOS-, PKA- and PI3K/Akt-dependent pathways and requires GLP-1 receptor. Molecular and Cellular Endocrinology 325 26-35. (doi:10.1016/j.mce.2010.04.022)

Furchgott RF \& Vanhoutte PM 1989 Endothelium-derived relaxing and contracting factors. FASEB Journal 3 2007-2018.

Ha SJ, Kim W, Woo JS, Kim JB, Kim SJ, Kim WS, Kim MK, Cheng XW \& Kim KS 2011 Preventive effects of exenatide on endothelial dysfunction induced by ischemia-reperfusion injury via KATP channels. Arteriosclerosis, Thrombosis, and Vascular Biology 32 474-480. (doi:10.1161/ATVBAHA.110.222653)

Harrison DG 1997 Cellular and molecular mechanisms of endothelial cell dysfunction. Journal of Clinical Investigation $1002153-2157$. (doi:10.1172/JCI119751)

Haversen L, Danielsson KN, Fogelstrand L \& Wiklund O 2009 Induction of proinflammatory cytokines by long-chain saturated fatty acids in human macrophages. Atherosclerosis 202 382-393. (doi:10.1016/j. atherosclerosis.2008.05.033)

Published by Bioscientifica Ltd. 
Inoguchi T, Li P, Umeda F, Yu HY, Kakimoto M, Imamura M, Aoki T, Etoh T, Hashimoto T, Naruse M et al. 2000 High glucose level and free fatty acid stimulate reactive oxygen species production through protein kinase $\mathrm{C}$ - dependent activation of $\mathrm{NAD}(\mathrm{P}) \mathrm{H}$ oxidase in cultured vascular cells. Diabetes 49 1939-1945. (doi:10.2337/diabetes.49.11.1939)

Kawasaki Y, Harashima S, Sasaki M, Mukai E, Nakamura Y, Harada N, Toyoda K, Hamasaki A, Yamane S, Yamada C et al. 2010 Exendin-4 protects pancreatic $\beta$ cells from the cytotoxic effect of rapamycin by inhibiting JNK and p38 phosphorylation. Hormone and Metabolic Research 42 311-317. (doi:10.1055/s-0030-1249035)

Kim F, Tysseling KA, Rice J, Pham M, Haji L, Gallis BM, Baas AS, Paramsothy P, Giachelli CM, Corson MA et al. 2005 Free fatty acid impairment of nitric oxide production in endothelial cells is mediated by IKKß. Arteriosclerosis, Thrombosis, and Vascular Biology 25 989-994. (doi:10.1161/01.ATV.0000160549.60980.a8)

Kim JY, Lim DM, Moon CI, Jo KJ, Lee SK, Baik HW, Lee KH, Lee KW, Park KY \& Kim BJ 2010 Exendin-4 protects oxidative stress-induced $\beta$-cell apoptosis through reduced JNK and GSK3 $\beta$ activity. Journal of Korean Medical Science 25 1626-1632. (doi:10.3346/jkms.2010.25.11.1626)

Kimura R, Okouchi M, Fujioka H, Ichiyanagi A, Ryuge F, Mizuno T, Imaeda K, Okayama N, Kamiya Y, Asai Ket al. 2009 Glucagon-like peptide-1 (GLP-1) protects against methylglyoxal-induced PC12 cell apoptosis through the PI3K/Akt/mTOR/GCLc/redox signaling pathway. Neuroscience 162 1212-1219. (doi:10.1016/j.neuroscience.2009.05.025)

Klaunig JE, Kamendulis LM \& Hocevar BA 2010 Oxidative stress and oxidative damage in carcinogenesis. Toxicologic Pathology 38 96-109. (doi:10.1177/0192623309356453)

Knudsen LB \& Pridal L 1996 Glucagon-like peptide-1-(9-36) amide is a major metabolite of glucagon-like peptide-1-(7-36) amide after in vivo administration to dogs, and it acts as an antagonist on the pancreatic receptor. European Journal of Pharmacology 318 429-435. (doi:10.1016/ S0014-2999(96)00795-9)

Koska J, Schwartz EA, Mullin MP, Schwenke DC \& Reaven PD 2010 Improvement of postprandial endothelial function after a single dose of exenatide in individuals with impaired glucose tolerance and recent-onset type 2 diabetes. Diabetes Care 33 1028-1030. (doi:10.2337/dc09-1961)

Kuhlencordt PJ, Gyurko R, Han F, Scherrer-Crosbie M, Aretz TH, Hajjar R, Picard MH \& Huang PL 2001 Accelerated atherosclerosis, aortic aneurysm formation, and ischemic heart disease in apolipoprotein E/endothelial nitric oxide synthase double-knockout mice. Circulation 104 448-454. (doi:10.1161/hc2901.091399)

Laursen JB, Somers M, Kurz S, McCann L, Warnholtz A, Freeman BA, Tarpey M, Fukai T \& Harrison DG 2001 Endothelial regulation of vasomotion in apoE-deficient mice: implications for interactions between peroxynitrite and tetrahydrobiopterin. Circulation 103 1282-1288. (doi:10.1161/01.CIR.103.9.1282)

Lee JE, Patel K, Almodovar S, Tuder RM, Flores SC \& Sehgal PB 2011 Dependence of Golgi apparatus integrity on nitric oxide in vascular cells: implications in pulmonary arterial hypertension. American Journal of Physiology. Heart and Circulatory Physiology $300 \mathrm{H} 1141-\mathrm{H} 1158$. (doi:10.1152/ajpheart.00767.2010)

Li Y, Perry T, Kindy MS, Harvey BK, Tweedie D, Holloway HW, Powers K, Shen H, Egan JM, Sambamurti K et al. 2009 GLP-1 receptor stimulation preserves primary cortical and dopaminergic neurons in cellular and rodent models of stroke and Parkinsonism. PNAS 106 1285-1290. (doi:10.1073/pnas.0806720106)

Lincz LF 1998 Deciphering the apoptotic pathway: all roads lead to death. Immunology and Cell Biology 76 1-19. (doi:10.1046/j.1440-1711.1998. 00712.x)

Nakatsubo N, Kojima H, Kikuchi K, Nagoshi H, Hirata Y, Maeda D, Imai Y, Irimura T \& Nagano T 1998 Direct evidence of nitric oxide production from bovine aortic endothelial cells using new fluorescence indicators: diaminofluoresceins. FEBS Letters 427 263-266. (doi:10.1016/S00145793(98)00440-2)

Nathanson D, Erdogdu O, Pernow J, Zhang Q \& Nyström T 2009 Endothelial dysfunction induced by triglycerides is not restored by exenatide in rat conduit arteries ex vivo. Regulatory Peptides 157 8-13. (doi:10.1016/j.regpep.2009.07.003)

Nyström T, Gutniak MK, Zhang Q, Zhang F, Holst JJ, Ahren B \& Sjöholm A 2004 Effects of glucagon-like peptide-1 on endothelial function in type 2 diabetes patients with stable coronary artery disease. American Journal of Physiology. Endocrinology and Metabolism 287 E1209-E1215. (doi:10.1152/ajpendo.00237.2004)

Parkes DG, Pittner R, Jodka C, Smith P \& Young A 2001 Insulinotropic actions of exendin-4 and glucagon-like peptide- 1 in vivo and in vitro. Metabolism 50 583-589. (doi:10.1053/meta.2001.22519)

Piro S, Spampinato D, Spadaro L, Oliveri CE, Purrello F \& Rabuazzo AM 2008 Direct apoptotic effects of free fatty acids on human endothelial cells. Nutrition, Metabolism, and Cardiovascular Diseases 18 96-104. (doi:10.1016/j.numecd.2007.01.009)

Ravassa S, Zudaire A, Carr RD \& Diez J 2011 Antiapoptotic effects of GLP-1 in murine HL-1 cardiomyocytes. American Journal of Physiology. Heart and Circulatory Physiology 300 H1361-H1372. (doi:10.1152/ajpheart. 00885.2010)

Royall JA \& Ischiropoulos H 1993 Evaluation of 2', 7'-dichlorofluorescin and dihydrorhodamine 123 as fluorescent probes for intracellular $\mathrm{H}_{2} \mathrm{O}_{2}$ in cultured endothelial cells. Archives of Biochemistry and Biophysics 302 348-355. (doi:10.1006/abbi.1993.1222)

Schisano B, Harte AL, Lois K, Saravanan P, Al-Daghri N, Al-Attas O, Knudsen LB, McTernan PG, Ceriello A \& Tripathi G 2012 GLP-1 analogue, Liraglutide protects human umbilical vein endothelial cells against high glucose induced endoplasmic reticulum stress. Regulatory Peptides 174 46-52. (doi:10.1016/j.regpep. 2011.11.008)

Schulz R, Rassaf T, Massion PB, Kelm M \& Balligand JL 2005 Recent advances in the understanding of the role of nitric oxide in cardiovascular homeostasis. Pharmacology \& Therapeutics 108 225-256. (doi:10.1016/j.pharmthera.2005.04.005)

Seeger FH, Haendeler J, Walter DH, Rochwalsky U, Reinhold J, Urbich C, Rossig L, Corbaz A, Chvatchko Y, Zeiher AM et al. 2005 p38 mitogenactivated protein kinase downregulates endothelial progenitor cells. Circulation 111 1184-1191. (doi:10.1161/01.CIR.0000157156.85397.A1)

Shiraki A, Oyama J, Komoda H, Asaka M, Komatsu A, Sakuma M, Kodama K, Sakamoto Y, Kotooka N, Hirase T et al. 2012 The glucagon-like peptide 1 analog liraglutide reduces TNF- $\alpha$-induced oxidative stress and inflammation in endothelial cells. Atherosclerosis 221 375-382. (doi:10.1016/ j.atherosclerosis.2011.12.039)

Steinberg HO, Paradisi G, Hook G, Crowder K, Cronin J \& Baron AD 2000 Free fatty acid elevation impairs insulin-mediated vasodilation and nitric oxide production. Diabetes 49 1231-1238. (doi:10.2337/diabetes.49.7.1231)

Suh KS, Chon S, Oh S, Kim SW, Kim JW, Kim YS \& Woo JT 2010 Prooxidative effects of green tea polyphenol (-)-epigallocatechin3-gallate on the HIT-T15 pancreatic $\beta$ cell line. Cell Biology and Toxicology 26 189-199. (doi:10.1007/s10565-009-9137-7)

Tesfamariam B \& Cohen RA 1992 Free radicals mediate endothelial cell dysfunction caused by elevated glucose. American Journal of Physiology $263 \mathrm{H} 321-\mathrm{H} 326$.

Tripathy D, Mohanty P, Dhindsa S, Syed T, Ghanim H, Aljada A \& Dandona P 2003 Elevation of free fatty acids induces inflammation and impairs vascular reactivity in healthy subjects. Diabetes 52 2882-2887. (doi:10.2337/diabetes.52.12.2882)

Verhaar MC, Westerweel PE, van Zonneveld AJ \& Rabelink TJ 2004 Free radical production by dysfunctional eNOS. Heart $90494-4955$. (doi:10.1136/hrt.2003.029405)

Verma S, Buchanan MR \& Anderson TJ 2003 Endothelial function testing as a biomarker of vascular disease. Circulation 108 2054-2059. (doi:10.1161/01.CIR.0000089191.72957.ED)

Wang XL, Zhang L, Youker K, Zhang MX, Wang J, LeMaire SA, Coselli JS \& Shen YH 2006 Free fatty acids inhibit insulin signaling-stimulated endothelial nitric oxide synthase activation through upregulating PTEN or inhibiting Akt kinase. Diabetes 55 2301-2310. (doi:10.2337) db05-1574) 
Xiang JN, Chen DL \& Yang LY 2012 Effect of PANDER in $\beta$ TC6-cell lipoapoptosis and the protective role of exendin-4. Biochemical and Biophysical Research Communications 421 701-706. (doi:10.1016/j.bbrc. 2012.04.065)

Xu J \& Zou MH 2009 Molecular insights and therapeutic targets for diabetic endothelial dysfunction. Circulation 120 1266-1286. (doi:10.1161/ CIRCULATIONAHA.108.835223)
Zhang XP \& Hintze TH 2006 cAMP signal transduction induces eNOS activation by promoting PKB phosphorylation. American Journal of Physiology. Heart and Circulatory Physiology 290 H2376-H2384. (doi:10.1152/ajpheart.00614.2005)

Zou MH, Cohen R \& Ullrich V 2004 Peroxynitrite and vascular endothelial dysfunction in diabetes mellitus. Endothelium 11 89-97. (doi:10.1080/ 10623320490482619)

Received in final form 17 January 2013

Accepted 23 January 2013

Accepted Preprint published online 23 January 2013
Published by Bioscientifica Ltd. 